EL MUHASABA: Jurnal Akuntansi (e-Journal)

Volume 12 , No. 1, Tahun 2021

P ISSN: 2086-1249 ; E ISSN: 2442-8922

\title{
VOLUNTARY COMPLIANCE DENGAN KONSEP KEADILAN PAJAK PERSPEKTIF IBNU KHALDUN BAGI WAJIB PAJAK
}

\author{
Sri Andriani \\ Universitas Islam Negeri Maulana Malik Ibrahim Malang, \\ Jl. Gajayana No. 50 Malang, 65144, Indonesia, \\ e-mail:sriandriani@akuntansi.uin-malang.ac.id
}

\begin{abstract}
This research is to identify and analyze the concept of voluntary compliance with the concept of Ibn Khaldun's perspective of tax justice for tax duty. Research with qualitative descriptive type which uses data through interviews with participants: religious leaders, tax officials, tax consultants, tax academics based on the slippery slope framework research results show that voluntary compliance / tax compliance can be defined as mandatory will taxes to be subject to tax regulations in a country. The measurement of compliance that is measured by the knowledge and concept of justice shows that 25 respondents chose strongly agree and 12 respondents chose agree from 37 respondents, meaning that the community realized that tax was the country's biggest source of revenue. Public knowledge about selfassessment shows an average of 3.35 , which means that the community has the potential to choose neutral in their knowledge, and 3.3 which shows the level of tax compliance. This tax compliance behavior arises because there is a fairly regulated income tax system, the way income tax is fairly distributed to each taxpayer, and the income tax that is charged is carried out fairly. The principles of convenience and productivity in the realization of taxes which are considered oppressive are emphasized with the concept of equality and neutrality. In other words, someone's awareness is recognized by how much someone's knowledge about the law, that someone's awareness is recognized by how much someone's knowledge about the law.
\end{abstract}

Keywords: Voluntary Compliance, Knowledge, Concept of Justice Ibnu Khaldun

\section{Abstrak}

Penelitian yang bertujuan untuk mengidentifikasi dan menganalisis konsep voluntary compliance dengan konsep keadilan pajak perspektif ibnu khaldun untuk wajiba pajak. Penelitian dengan jenis diskriptif kualitatif yang menggunakan data melalui wawancara dengan partisipan wajib pajak (UKM), tokoh agama, pegawai pajak, konsultan pajak, akademisi perpajakan) yang dilandasakan pada slippery slope framework hasil penelitian menunjukan bahwa voluntary compliance / kepatuhan pajak dapat didefinisikan sebagai kemauan wajib pajak untuk tunduk terhadap regulasi perpajakan di suatu negara. Pengukuran kepatuuhan yang diukur dengan pengetahuan dan konsep keadilan menunjukkan 25 responden memilih sangat setuju dan 12 responden memilih setuju dari 37 responden artinya masyarakat menyadari sumber penerimaan pajak terbesar adalah pajak. Pengetahuan masayarat akan self assissment menunjukkan rata-rata 3,35 yang artinya masyarakat berpotensi memilih netral dalam pengetahuannya, serta 3,3 yang menunjukkan tingkat kepatuhan pajak. Perilaku kepatuhan pajak ini timbul 
Sri Andriani : Voluntary Compliance Dengan Konsep Keadilan Pajak Perspektif Ibnu Khaldun Bagi Wajib Pajak

karena adanya sistem pajak penghasilan yang diatur secara adil, cara pembebanan pajak penghasilan didistribusikan secara adil kepada setiap wajib pajak, dan pajak penghasilan yang dibebankan dilakukan secara adil. Prinsip-prinsip kemudahan dan produktivitas dalam realisasi pajak yang dianggap tidak memindas ditekankan dengan konsep kesamarataan dan kenetralan. Dengan kata lain kesadaran sesorang itu didahuli dari seberapa besar pengetahuan seseorang tentang hukum tersebut, bahwa kesadaran sesorang itu didahuli dari seberapa besar pengetahuan seseorang tentang hukum tersebut.

Kata kunci: Kepatuhan, Pengetahuan, Konsep Keadilan Ibnu Khaldun

\section{PENDAHULUAN}

Maikel (2017) menjelaskan bahwa Anggaran Pendapatan dan Belanja Negara (APBN) Tahun 2017mentargetkan pajak sebesar Rp. 1.307,6 triliun, namun berdasrkan kesepakatan dari pihak-pihak (Bank Indonesia, DPR), maka target pajak sebesar Rp. 1.283,6 triliun. Tax rasio sebagai pengukur kepatuhan wajib pajak menurut Direktorat Jenderal Pajak (Ditjen Pajak) melalui Direktur penyuluhan, pelayanan, dan Hubungan Masyarakat Ditjen Pajak, Hestu Yoga Saksama masih renncdah yaitu 10,3\%(5 tahun),hal ini didukung oeh hartono (2017) yang menyatakan hal yang sama. Untuk ebih jelasnya tampak pada grafik berikut:

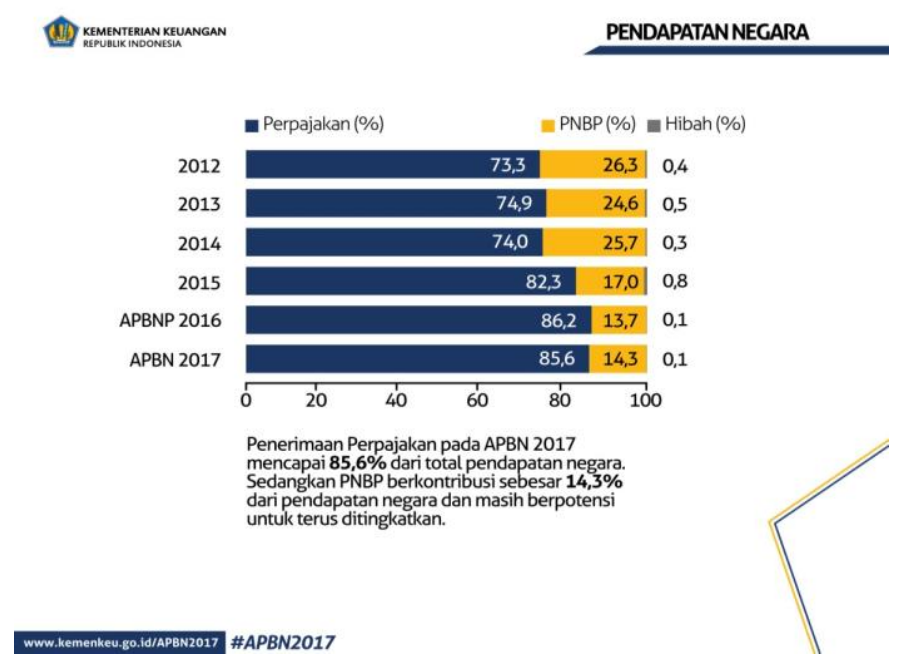

Gambar 1. Tingkat Pendapatan Negara dibandingkan dengan Target Pajak

Dalam gambar 1 tampak bahwa penerimaan pajak masih menjadi dominasi pendapatan yang digunakan sebagai pembiayan Negara, sehingga sangat dituntut kepatuhan wajib pajak yang ada. Menurut Martowardojo (2013), Dalam rangka meningkatkan kepatuhan wajib pajak yang masih rendah analis lebih lanjut tentang kondisi antara warga Negara. Perbandingan data antara Jumlah warga negara yang mendaftar wajib pajak dibandingkan dengan PTKP (Penghasilan Tidak Kena pajak masih rendah yaitu 20.000.000/60.000.000, artinya terdapat 40.000 .000 warga Negara belum mendaftar sebagai wajib pajak 
Sri Andriani : Voluntary Compliance Dengan Konsep Keadilan Pajak Perspektif Ibnu Khaldun Bagi Wajib Pajak

dan secara otomatis tidak menjalankan kewajiban perpjakannnya sebagai wajib pajak.

Sedangkan dari data badan usaha terdapat 5 juta sudah terdaftar di pemerintah, yang mendaftarkan menjadi wajib pajak sebanyak 1,9 juta telah membayar pajak/melapor, selisih yang signifikan. Otoritas pajak di seluruh dunia dihadapkan pada kasus yang sama yaitu kepatuhan pajak (OECD, 2001:3). Sisi lain kepatuhan juga di pengaruhi oleh budaya spiritual (integrasi hidup, integrasi ibadah integrasi hubungan (andriani, slamet, djalal, 2015). Beberapa penelitian juga menunjukkan banyak faktor yang mempengaruhi kepatuhan wajib pajak.

Rendahnya kepatuhan wajib pajak disebabkan beberapa faktor (Abdullah (1428 H/2007) seperti faktor psikologis (nafsiyah) yang terdiri dari: sikap berat melepas hak miliknya (hartanya), persepsi tentang ketidakadilan pajak, Pajak tidak memberikan kontraprestasi langsung baginya, pajak tidak digunakan untuk kepentingan rakyat, pemahaman negara mengambil > dari pada yang diberikan pada masyarakat dan adanya empati karena orang lain melakukan hal sama. Sedangkan dari sisi orang Islam, ada sebagain yang menganggap pajak tidak wajib tetapi zakat yang penting, Namun pemerintah tetap mensosialisasikan bahwa pentingnya pajak sebagai sumber pendapatan terbesar ngera yang berfungsi membiayai penyelenggaraan Negara. Sisi lain andriani (2016) menyatakan bahwa kepatuhan lebih komplek pengaruhnya yaitu dilihat dari sisi Taxpayers right, taxpayers rights, tax fairness dimensions, persepsi iklim keorganisasian,, kepercayaan public, otoritas pajak dan target pajak, zakat pengurang pajak.

Penerimaan pajak diharapkan meningkat dengan pemerintah mengeluarkan PP No. 46 tahun 2013 tentang Pajak Penghasilan yang bersifat final sebedar $1 \%$ atas Penghasilan dari kegiatan Usaha yang diperoleh wajib pajak atas Peredaran Bruto tidak melebihi Rp.4.800.000.000,- dalam 1 (satu) tahun. Sehingga memunculkan berbagai sikap dan argumentasi. Hal berbeda dengan kepastian perlakukan atas Undang-Undang Pajak Penghasilan No. 36 tahun 2008. Pajak penghasian final merupakan produk yang cacat hukum karena pertimbangan yang diakui adalah peghasilan bruto bukan margin, pendapat pengusaha omset merupakan selisih pendapatan dikurangi beban/biaya, sehingga kerugian bisa terjadi jika sepenuhnya mematuhi peraturan atas pph final PP 46/2013 (Priyantarno, 2013). Konsep keadilan yang termasuk equity principle dalam pengenaan PPH Final untuk wajib pajak dengan penghasilan di bawah 4,8 milyard, (Tambunan, 2013) belum mempunyai konsep keadilan, hal ini terbukti pengukuran kewajiban tidak didasarkan pada kemampuan membayar/ability to pay saja.

Selain pendapat tersebut, menunjukkan sebelum perlakuan PP No. 46 Thn 2013 UMKM dapat memperhitungkan pajaknya dengan norma atau pembukuan yang menunjukkan nilai pajak disetor lebih kecil, Nugraheni (2010: 
Sri Andriani : Voluntary Compliance Dengan Konsep Keadilan Pajak Perspektif Ibnu Khaldun Bagi Wajib Pajak

77). Sisi lain system self assessment bagi wajib pajak merupakan kewajiban yang memberikan kepercayaan penuh kepada wajib pajak untuk mendaftar, menghitung, menyetor dan melaporkan kewajiban pajaknya, memberikan dampak, jika memang wajib pajak dapat memegang amanah pastinya kepatuhan pajak semakin tinggi tetapi sebaliknya, Hal ini menjadi di fenomena di Indonesia yang tax ratio rendah maka kepatuhan juga rendah.

Muhammad dan Kurniawan (2014) menjelaskan bahwa petunjuk (Hudan) dan pedoman (guidance) bagi umat manusia yang benar adalah agama Islam (Dinul haq). Sebagai agama yang benar Islam mengajarkan dan mengatur persoalan "ubudiah, hubungan antara manusia secara vertikal dan secara horizontal. Islam mengatur hal-hal yang berhubungan dengan kehidupan manusia dalam muamalah, termasuk transaksi perdagangan dan kegiatan lain yang menyokong keberlanjutan (continuity) dan kebermaknaan (meaning) kehidupan manusia untuk kedamaian (silm) dan kebahagiaan manusia (happines). Ibnu Khaldun telah menekankan prinsip perpajakannya dengan sangat jelas dalam muqaddimah. Menurut (Syari,2016) Ibnu Khaldun menyimpulkan bahwa "faktor paling penting untuk menciptakan atmosfer bisnis yang menguntungkan adalah meringankan sebanyak mungkin beban pajak pada pelaku bisnis, dengan tujuan menggalakkan dunia usaha dengan cara memberikan jaminan keuntungan yang lebih besar." Hal ini ia jelaskan sebagai berikut: "ketika beban pajak ringan, rakyat mempunyai insentif untuk berusaha lebih aktif. Karena itu, dunia usaha menjadi berkembang, yang menimbulkan kepuasan yang lebih besar di kalangan rakyat karena rendahnya beban pajak, sementara penerimaan dari pajak juga akan meningkat, dilihat dari keseluruhan sumber lahan pajak" Selain itu: "Kebutuhan Negara yang meningkat akan meingkatkan target pajak dan secara otomatis penerimaan Negara juga akan meningkat. Peningkatan yang gradual masyarakat akan terbiasa dengan kondisi ini, sisi lain insentif atas kewajiban perpajakan masyarakat juga akan lebih sensitive, lebih lanjut perkembangan usaha akan terhambat (merosot) yang diikuti dengan realisasi pajak yang menurun. Pada Akhirnya dunia usaha/perekonomian akan muncul: kondisi perekonomian yang depresi menyebabkan realisasi pajak menurun karena laju pajak yang lebih tinggi, sebaliknya perekonomian yang makmur menyebabkan realisasi pajak yang lebih tinggi karena laju pajak yang rendah.

Konsep keadilan terhadap harta benda menurut (Sayri,2016) "ketahuilah bahwa bertindak tidak adil terhadap harta benda orang lain akan mengurangi kesediaan mereka untuk mencari kehidupan dan memperoleh kekayaaan dan jika ketidaksediaan untuk memperoleh kehidupan itu terus terjadi, mereka akan berhenti bekerja. makin besar tekanan, makin besar dampaknya pada usaha bekerja mereka dan jika rakyat tidak mau mencari penghidupan dan berhenti kerja, pasar akan mandeg dan kondisi rakyat akan memburuk". Karena itu, ia mendukung keadilan dalam perpajakan. Tentunya korelasi antara kepatuhan 
Sri Andriani : Voluntary Compliance Dengan Konsep Keadilan Pajak Perspektif Ibnu Khaldun Bagi Wajib Pajak

warga negara terhadap pajak, konsep keadilan menjadi hal yan menarik untuk diteliti, hal ini jika di lihat dari sisi ekonomi makro tampak bahwa kondisi ekonomi Negara sangat dipengaruhi oleh pajak (perlu diketahu $80 \%$ pendapatan Negara dari pajak). Kondisi ini yang menuntut Negara harus berkerja keras meningkatkan realisasi pajak, sisi lain masyarakat kurang antusias jika membahas pajak? Maka program tax amnesty menjadi salah satu pilihan dalam meningkakan realisasi pajak yang masyarakat juga merasa untung. Realisasi pajak berasal dari pajak penghasilan badan (PPh Badan), pajak pertamahan nilai (PPN), pajak final.

PPh final yang menjadi sumber penghasilan sebesar $37 \%$ dari total penerimaan menunjukkna bahwa ada 3 hal yang perlu diselaraskan dalam konsep keadilan melalui konsep voluntary compliance, yaitu revenue productivity, horizoltal equity vertical equity, dan easy of administrasi. Dalam konsep ekonomi konvensional berdasarkan ibnu khaldun akan sangat menarik untuk dikaji, tentang keadilan dalam kepatuhan wajib pajak. Dari latar belakang maka penelitian ini bertujuan untuk mengetahui dan menganalisa bagaimana konsep Voluntary Compliance dalam pengetahuan dan keadilan Pajak Perspektif Ibnu Khaldun untuk wajib pajak.

\section{KAJIAN PUSTAKA}

\section{Konsep Keadilan}

Konsep keadilan adalah suatu kebenaran yang ideal menyangkut moral baik menyangkut benda atau orang menurut Jhon Rawls (1999) adalah kebenaran pada sisem pemikiran yang memberikan kelebihan (virtue) pertama pada institut sosial. Keadilan menurut bahasa Arab kata adil berarti tengah, adapun pengertian adil adalah memberikan apa saja sesuai dengan hak nya. Keadilan berarti tidak berat sebelah, menempatkan sesuatu di tengah-tengah, tidak memihak, berpihak kepada yang benar, tidak sewenang-wenang. Keadilan juga memiliki pengertian lain yaitu suatu keadaan dalam kehidupan masyarakat, berbangsa dan bernegara memperoleh apa yang mnjadi haknya sehingga dapat melaksanakan kewajibannya. Menurut Kamus Besar Bahasa Indonesia (KBBI) keadilan merupakan suatu hal yang tidak berat sebelah atau tidak memihak serta tidak sewenang-wenang. Arti keadilan yaitu, tidak berat sebelah, kejujuran, kelurusan, dan keikhlasan. Dalam QS. An-Nisa: 58, Islam memerintahkan kepada setiap manusia untuk berbuat adil atau menegakkan keadilan pada setiap tindakan dan perbuatan yang dilakukan,

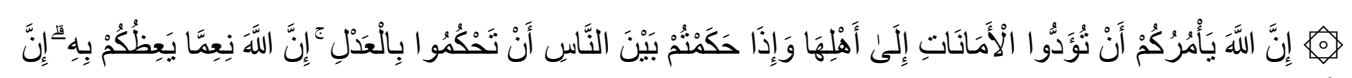

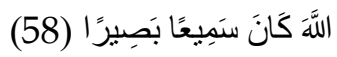

Dalam QS. An-nissa: 135 Allah memerintahkan kepada orang-orang yang beriman untuk menjadi penegak keadilan, yaitu :

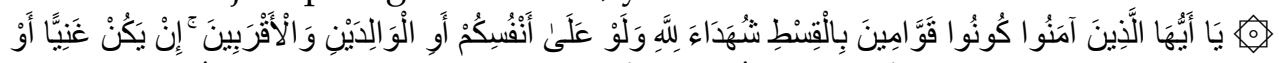

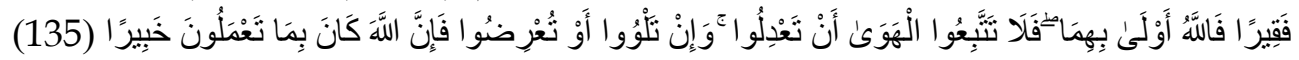


Sri Andriani : Voluntary Compliance Dengan Konsep Keadilan Pajak Perspektif Ibnu Khaldun Bagi Wajib Pajak

Keadilan dilihat dari sisi keadilan pada (1) hak Allah (tidak menggunakan nikmat-Nya untuk bermaksiat kepada-Nya, bahkan menggunakan untuk ketaatan kepada-Nya) dan (2) dari sisi hak hamba-hamba Allah (memenuhi kewajibanmu terhadap orang lain, sebagaimana kamu menuntut hakmu). Penerapan keadilan adalah bersikap adil dalam berbicara, oleh karena itu, dia tidak boleh menghukumi salah satu dari dua perkataan atau salah satu dari dua orang yang bersengketa karena ada hubungan hasab dengnannya atau karena lebih cenderung kepadanya. Hal ini ditegaskan dalam QS. As-syuura : 15, yakni :

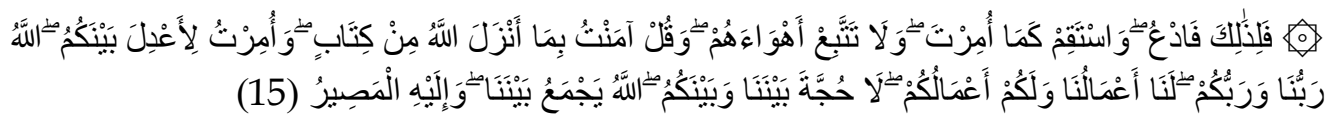

Maka karena itu serulah (mereka kepada agama ini) dan tetaplah sebagaimana diperintahkan kepadamu dan janganlah mengikuti hawa nafsu mereka dan katakanlah: "Aku beriman kepada semua Kitab yang diturunkan Allah dan aku diperintahkan supaya berlaku adil diantara kamu. Allah-lah Tuhan kami dan Tuhan kamu. Bagi kami amalamal kami dan bagi kamu amal-amal kamu. Tidak ada pertengkaran antara kami dan kamu, Allah mengumpulkan antara kita dan kepada-Nya-lah kembali (kita)".

Dalam sebuah Hadist, "Sesungguhnya orang-orang yang berlaku adil akan berada di atas punggung yang terbuat dari cahaya disebelah kanan Allah azza wa jalla dan kedua sisinya dalam keadaan baik, yaitu orang-orang yang berlaku adil dalam hukum, dalam keluarga dan dalam tugas yang diberikan kepada mereka "(HR. Muslim). Dalam ayat yang lain jyga dijelaskan untuk menetapkan suatu hukum haruslah berlaku adil, dalam firman Allah QS. An-Nisa:5. Yang artinya:

"sungguh, Allah mrnyuruhmu menyampaikan amanat kepada yang berhak menerimannya dan apabila kamu menetapkan hukum diantara manusia hendaknya kamu memnetapkannya dengan Adil. Sungguh Allah sebaik-baik yang memberi pengajaran kepadamu. Sungguh Allah maha mendenggar dan maha mehihat".

\section{Tax Fairness Dimensions (Dimensi Keadilan Pajak)}

Menurut Albari (2008:280) Persepsi masyarakat atas keadilan sistem perpajakan yang berlaku dipengaruhi oleh pelaksanaan perpajakan yang baik, persepsi juga mempengaruhi perilaku kepatuhan pajak dan perilaku penghindaran pajak (tax evasion). pajak jika merasa perpajakan yang berlaku tidak adil. Jika masyarakat cenderung tidak patuh dan menghindari kewajiban pajak yang disebabkan perlakukan tidak adil. Richardson (2006) menemukan bahwa hasil dari penelitian-penelitian mengenai pengaruh dimensi keadilan pajak terhadap tingkat kepatuhan pajak ini tidak konsisten. Salah satu alasan utama ketidakkonsistenan hasil ini adalah sifat multidimensional dari keadilan pajak sebagai variabel kepatuhan pajak yang juga dipengaruhi budaya. 
Sri Andriani : Voluntary Compliance Dengan Konsep Keadilan Pajak Perspektif Ibnu Khaldun Bagi Wajib Pajak

Andriani (2015) menyatakan ada lima dimensi keadilan pajak yaitu terdiri dari: (1) Keadilan umum/general fairness, (2) Timbal balik dari pemerintah /exchanges with government, (3) Kepentingan pribadi/self interest, (4) special provisions, (5) Tarif pajak/ tax rate

\section{Konsep Voluntary Compliance}

Konsep dalam tax administration voluntary compliance dapat diperoleh dengan biaya yang minimal (OECD). Slippery Slope Framework didasari antara kurangnya fiskus sebagai sumber daya dengan wajib pajak yang lebih besar, sehingga diharapkan fiskus dan wajib pajak bisa menjadi partner dalam menjalankan kewajiban perpajakan. Maka Slippery Slope Framework dapat diterapkan sebagai pendekatan gabungan. Pendekatan ini menunjukkan bahwa kepatuhan dapat ditimbulkan karena adanya (1) unsur pemaksaan/enforced compliance, dan (2) kesadaran sendiri wajib pajak (voluntary compliance). Hal ini dijelaskan dalam Gambar 2 dan 3, berikut:

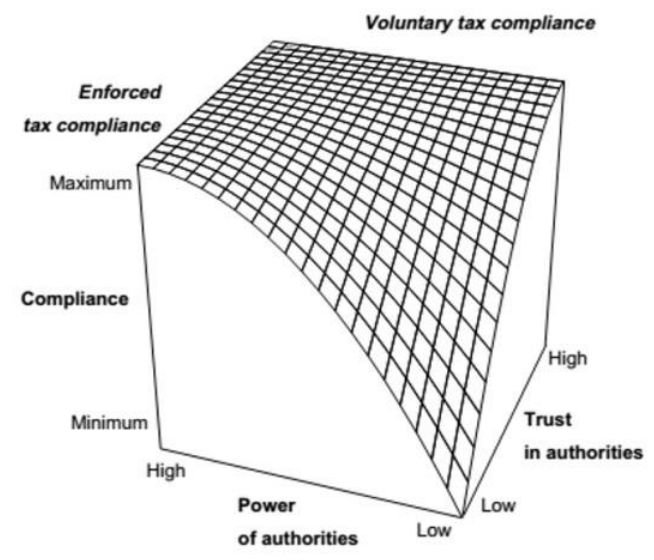

Gambar 2. Slippery - Slope Framework

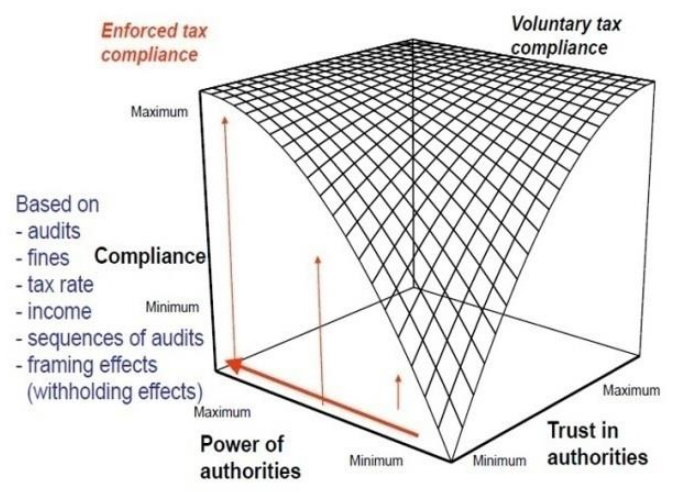

\section{Gambar 3. Enforced Compliance}

Tindakan pemaksaan oleh penguasa (power of authority) memunculkan Enforced compliance. Korelasi yang muncul adalah sebagai berikut: Fiskus/Pemerintah yang menbuat kebijakan/peraturan melakukan pemeriksaan secara rutin dan secara berkala, hal ini akan berkorelasi dengan meningkatnya penagihan, dengan penagihan yang meningkat akan memunculkan seringnya 
Sri Andriani : Voluntary Compliance Dengan Konsep Keadilan Pajak Perspektif Ibnu Khaldun Bagi Wajib Pajak

penuntutan yang ada akhirnya akan berengaruh terhadap kepathan wajib pajak. Wajib pajak yang nekat tidak patuh sangsinya jelas. Kekuasaan petugas pajak menjadikan kepatuhan semakin meningkat dan terus meningkat (Gambar 2). Sehingga pemeriksaan, penyidikan, sanksi pidana, sanksi denda, penyitaan adalah hal yang menyeramkan untuk dibicarakan. Wajib pajak percaya kepada pemegang kekuasaan juga akan meningkatkan kepatuhan, jadi tidak dengan paksaan melainkan kesadaran wajib pajak. Beberapa ilustrasi kasus aturan pajak yang yang susah di pahami, urusan pajak berbelit-belit, adanya jebakan batman, penggunaan uang pajak tidak untuk kepentingan publik, opini publik, ikutikutan tidak patuh, norma sosial, kepercayaan, semua hal tersebut sebenarnya pada konsep Tax moral seperti tampak pada gambar 4

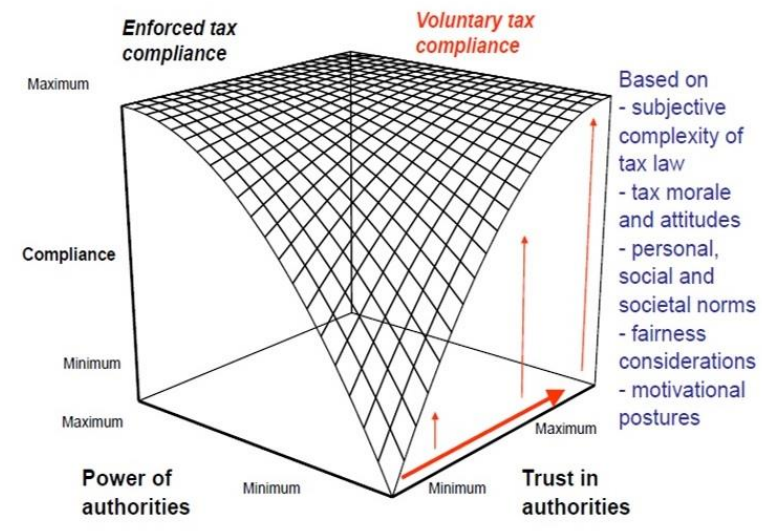

Gambar 4. Voluntary Compliance

Berdasarkan gambar di atas maka tampak bahwa enforced dan voluntary compliance saling berhubungan. Pemeriksaan yang dillakukan dengan kekerasan dapat dijadikan sarana pada enforced compliance. Ilustrasinya sebagai berikut: "Jika tindakan law enforcement yang dilakukan oleh petugas pajak dirasa tidak adil oleh wajib pajak maka,maka kepercayaan wajib pajak/trust akan menurun, dampaknya adalah voluntary compliance menurun, penurunan yang terjadi secara otomatis menurunkan juga overall compliance, hal inilah yang pada akhirnya realisasi pajak juga menurun. Aktivitas law enforcement disebabkan adanya peningkatan responnya otoritas pajak kepada wajib pajak. Hal ini bertolak belakang dengan kondisi wajib pajak yang mengangap keadilannya semakin tidak adil, sehingga wajib pajak akan berusaha lebih keras untuk mengurangi pajaknya salah satya melalui tax evasion. Efeknya daari ilustrasi tersebut adalah ketidakpatuhan semakin meningkat atau perlawanan terhadap kepatuhan menjadi semakain besar. Kondisi yang bertolak belakang membuat penegakan hukum semakin ditingkatkan oleh otoritas pajak, hal ini tampak dalam kebijakan penentuan tindakan law enforcement yang dibuat yaitu self regulation dan prosecution. Untuk detailnya ilustrasi tersebut tampak dalam gambar 4 berikut: 
Sri Andriani : Voluntary Compliance Dengan Konsep Keadilan Pajak Perspektif Ibnu Khaldun Bagi Wajib Pajak

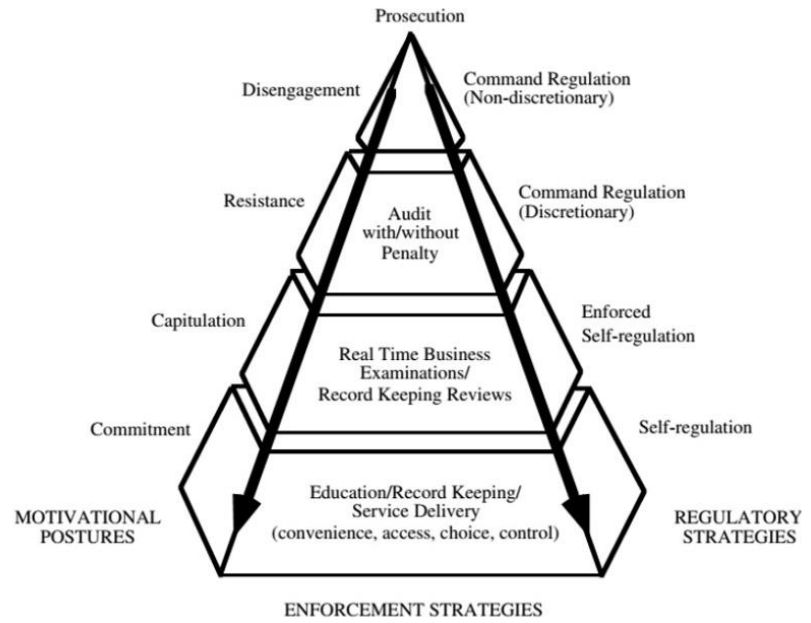

Gambar 5. Konsep Segmentasi Pasar

Dari gambar 5 menunjukkan bahwa konsep segmentasi pasar menunjukkan pembagian customer menjadi beberapa golongan. Ilustrasi kasus $\mathrm{X}$ dan $\mathrm{Y}$, berdasarkan konsep kerangka yang ada adalah, $\mathrm{X}$ dan $\mathrm{Y}$ adanya perlakukan yang berbeda. Kasus $X$ diberikan kepercayaan dan keleluasaan, sehingga kepatuhan meningkat, jika terjadi ketidakapatuhan maka diberikan peringatan. Yang satunya kasus $Y$, pengawasan dilakukan secara ketat sehingga jika ada pelanggaran pasti akan diberikan sanksi yang sesuai.

\section{METODE}

Jenis penelitian causal comparative and description, penelitian ini menggambarkan bagaimana dampak perlakuan Voluntary Compliance Dengan Konsep Keadilan Pajak Perspektif Ibnu Khaldun. Data primer diperoleh dengan menyebarkan kuisioner, wawancara atau tanya jawab. Partisipan yang diwawancarai adalah: Wajib pajak (UKM), tokoh agama, pegawai pajak, Konsutan pajak, Akademisi perpjakan). Analisis data dalam penelitian ini menggunakan kualitatif analysis dengan langkah sebagai berikut:

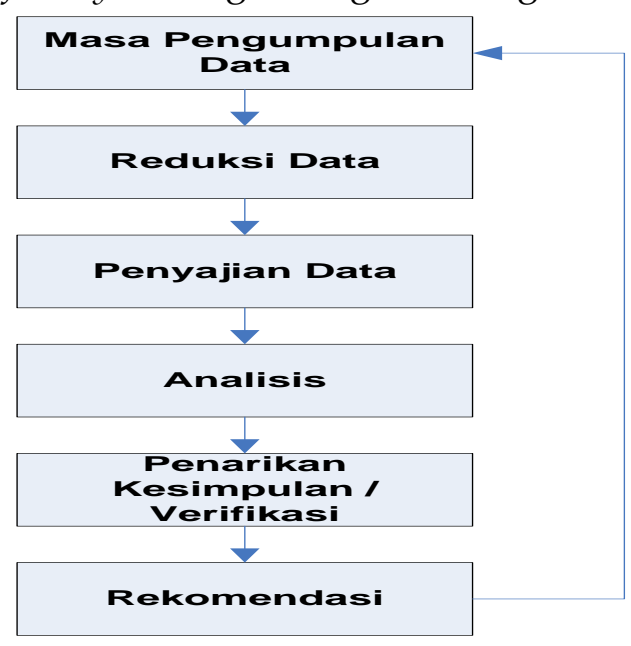


Sri Andriani : Voluntary Compliance Dengan Konsep Keadilan Pajak Perspektif Ibnu Khaldun Bagi Wajib Pajak

\section{HASIL DAN PEMBAHASAN}

\section{Volunntary Compliance PPh Final}

Penerimaan pajak dijadikan sumber penerimaan utama yang selalu diunggulkan oleh Negara karena sifat pajak yang diatur eraturan dengan ketat, meskipun konsep self assessment. Setiap warganegara memmpunyai kewajiban yang sama untuk mendukung dalam pemerintah dalam menjalankan kelangsungangan hidup Negara, pajak yang menjadi faktor utama (80\%) dalam dalam penerimaan nagera maka kewajiban masyarakat terhadap Negara juga di tuntut dan hal ini sejalan dengan hak masyarakat. Self assessment adalah system perpajakan di Indonesia yang meberikan hal sepenuhnya kepada wajib pjak untuk mendaftar sendiri kewajinan sebagai wajib pajak disaat syarat materiil (bagi yang telah mencapai titik nisbah-threshold-perpajakan) dan syarat formil terpenuhi, wajib pajak juga mempunyai kebebasan dalam menghitung pajaknya, menyetorkan pajaknya dan melaporkan pajaknya kepada pemerintah

Konsep self assessment di Indonesia harus diimbangi dengan sosialisasi kepada wajib ajak, sehingga wajib pajak akan memperoleh fasilitas perpajakan, yaitu trdiri dari: (1) Hak dan kewajiban wajib pajak dalam hal perpajakan dilaksanakan degan konsep kepercayaan penuh pemerintah, (2) Warga Negara yang baik akan diberikan tempat yang terhormat. Sedangkan ciri-ciri self assessment terdiri dari: kepastian hukum, perhitungan sederhana, aplikasi lebih mudah, ada rasa keadilan oleh wajib pajak. Maka harapan untuk wajib pajak dalah Tax consciousness, tumbuh kejujuran, Tax mindedness, Tax discipline

Pelunasan pajak dapat dilakukan dengan dibayarkan pihak pemotong atau membayar sendiri dengan periodesasi masa dan tahunan. Dari perhitungan pajak tahunan di korelasikan dengan pajak yantelah dihitungdengan jumlah pajak yang di setor. Sesuai dengan hasil wawancara pada fiskus yang menyatakan bahwa "pemahaman wajib pajak memang sampai saat ini paling tidak perlu adanya pengetahuan dasar yaitu mengetahui cara menghitung usahanya dengan benar dan cara melapornya". Sehingga dari pernyataan salah satu fiscus ini menunjukkan bahwa self assessment itu sangat penting, baik dalam perhitungan dan pelaporan pajaknya.

Untuk mengetahui tingkat voluntary compliance wajib pajak bagi start up dan umkm, penelitian ini selain menggunakan system wawancara, juga melalui system kuesioner yang dibagikan ke wajib pajak.

Tabel 1. Voluntary Compliance

\begin{tabular}{|c|c|c|c|c|c|c|}
\hline \multirow{2}{*}{ No } & \multirow{2}{*}{ Pertanyaan } & \multicolumn{5}{|c|}{ Alternatif jawaban } \\
\hline & & SS & $S$ & $\mathrm{~N}$ & Ts & Sts \\
\hline \multicolumn{7}{|c|}{ Variabel x1pengetahuan perpajakan } \\
\hline 1 & $\begin{array}{l}\text { Pemahanan sumber penerimaan terbesar } \\
\text { Negara adalah pajak }\end{array}$ & 25 & 12 & & & \\
\hline 2 & $\begin{array}{l}\text { Pengetahuan bahwa self asssessment bagi } \\
\text { wajib pajak diberikan kepercayaan }\end{array}$ & & 14 & 22 & 1 & \\
\hline
\end{tabular}


Sri Andriani : Voluntary Compliance Dengan Konsep Keadilan Pajak Perspektif Ibnu Khaldun Bagi Wajib Pajak

\begin{tabular}{|c|c|c|c|c|c|}
\hline & sepenuhnya & & & & \\
\hline 3 & $\begin{array}{l}\text { Kepatuhan wajib pajak dapat ditingkatkan } \\
\text { dengan sistem self assessment }\end{array}$ & & 14 & 20 & 3 \\
\hline 4 & $\begin{array}{l}\text { Pajak bertujuan untuk membiayai } \\
\text { pengeluaran rutin di daerah serta untuk } \\
\text { pembangunan nasional bahkan untuk } \\
\text { pengembangan pendidikan dan ekonomi } \\
\text { masyarakat. }\end{array}$ & 19 & 18 & & \\
\hline 5 & $\begin{array}{l}\text { Pengetahuan tentang } \\
\text { pelaporan spt dapat } \\
\text { kepatuhan wajib pajak. }\end{array}$ & & 11 & 24 & 2 \\
\hline
\end{tabular}

Dari hasil koesioner tersebut dapat dilihat bahwa 25 responden memilih sangat setuju dan 12 responden memilih setuju dari 37 responden artinya masyarakat menyadari bahwa. Pengetahuan masayarat akan self Assissment menunjukkan rata-rata 3,35 yang artinya masyarakat berpotensi memilih netral dalam pengetahuannya, serta 3,3 yang menunjukkan tingkat kepatuhan pajak.

\section{Konsep Keadilan}

Pengertian keadilan adalah tidak berat sebelah; tidak memihak berpihak kepada yang benar; berpegang pada kebenaran; sepatutnya; tidak sewenangwenang (Kamus Bahasa Indonesia).Konsep keadilan dalam islam sesuai dengan firman Allah sebagai berikut:

Artinya: "Wahai orang-orang yang beriman. Jadilah kamu sebagai orang-orang yang selalu menegakkan keadilan karena Allah, (ketika) menjadi saksi dengan adil. Dan janganlah kebencianmu terhadap suatu kaum mendorong kamu untuk berlaku tidak adil. Berlaku adillah, karena (adil) itu lebih dekat terhadap taqwa. Dan bertaqwallah kepada Allah, sesungguhnya Allah maha teliti terhadap apa yang kamu kerjakan." Allah QS. Al-Maidah: 8

Pada Hadist: orang-orang yang berlaku adil akan diberikan kebahagian, sepeti riwayat Rasulullah SAW memberikan janji kebahagiaan kepada orangorang yang berlaku adil dalamd sabdanya yang diriwayatkan dari Abdullah bin Umar ra "Sesungguhnya orang-orang yang berlak adil akan berada diatas punggung yang terbuat dari cahaya disebelah kanan Allah azza wa jalla dan kedua sisinya dalam keadaan baik, yaitu orang-orang yang berlaku adil dalam hukum, dalam keluarga dan dalam melaksanakan tugas yang diberikan kepada mereka". (HR. Muslim)

Keadilan sistem perpajakan dipengaruhi oleh pelayanan yang baik dari Negara kepada masyarakat/wajib pajak, sehingga kecendrungan wajib pajak untuk patuh semakin tampak. Hasil wawancara juga mnunjukkan bahwa memungut pajak secara substansi memerlukan keadailan baik dalam pemeriksaan, dasar pemungutannya, dasar pengenanya. Sisi lain tokoh agama menjelaskan konsep keadian adalah sesuatu yang cenderung abtrak dan 
Sri Andriani : Voluntary Compliance Dengan Konsep Keadilan Pajak Perspektif Ibnu Khaldun Bagi Wajib Pajak

dipersepsikan orang subyektifitasnya tinggi. Pedapat ini di dukung dengan konsep keadilan pada hukum pajak yaitu: “Asas keadilan mengatakan bahwa pajak itu harus adil dan merata. Pajak dikenakan kepada orang-orang pribadi sebanding dengan kemampuannya untuk membayar pajak tersebut dan juga sesuai dengan manfaat yang diterimanya dari negara".

Pendapat lainnya Wajib pajak telah melakukan kewajibannya dalam menyetor pajak kepada pemerintah dengan kata lain masyarakat/wajib pajak mau mengorbankan sebagain hartanya untuk diserahan ke Negara, kossep ini dapat disebut adil dari sisi masyarakat dan negara. Kata adil mempunyai beberapa pengertian, mengenakan pajak kepada masyarakat yang memenuhi syarat materiil dan formil serta sesuai dengan kemampuan masing-masing secara umum dan merata disebut adil. Adil berdasarkan ketentuan umum perpajakan adalah adanya hak yang sama kepada wajib pajak berupa: keberatan, penundaan pembayaran, dan bading unutk kasus perpajakan yang terjadi. Konsep keadilan juga muculdari adanya pandangan terhadap azas pemungutan pajak yang dapat dianalisis dari bebrapa sudut.

Asas pemungutan pajak menurut Brotodihardjo (2003), menyebutkan bahwa (1) adanya keseimbangan antara kemampuan masing-masing subyek pajak atas penghasillan yang dinikmati dengan tekanan pajak dengan kata lain ada asas pembagian/asas kepentingan, (2) Diskriminasi pada wajib pajak tidak boleh dilakukan oleh Negara/ Konsep asas equality, (3) Pembayaran pajak yang dilakukan oleh subyek pajak harus dilakukan secara terang/certain, dan tidak mengenal kompromi/notarbitrary. Konsep asas certainty menuntut kepastian hukum bagi subyek ppajak dan objek pajaknya, konsep ini dapat diuraikan dengan: Teknik "Every tax ought to be levied at the time, or in the manner, in which it is most likely to be convenient for the contributor to pay $I^{\prime \prime}$, artinya pajak yang yang dipungut kepada wajib pajak dikenakan pada saat yang tepat dan waktu yang paling dekat dengan waku perolehan penghasilan. Kedua "Every tax ought to be so contrived as both to take out and to keep out of the pockets of the people as little as possible over and above what it brings into to public treasury of the State" artinya pemungutan pajak dilakukan secara efisien yaitu mempertimbangkan biaya sekecil kecilnya untuk mendapat realisasi pajak yang maksimal.

Menurut Parwito (2006) Prinsip keadilan dibedakan menjadi 2, yaitu (1) prisip keadilan horizontal dan prinsip keadilan vertical, dengan uraian sebagai berikut:"... Keadilan horizontal dalam perspektif pajak mengandung makna, untuk wajib pajak dengan kondisi kemampuan atau penghasilan yang sama harus dikenakan jumlah pajak yang sama. Sementara keadilan vertikal diartikan semakin tinggi kemampuan ekonomis wajib pajak, semakin tinggi pula beban pajak yang dikenakan. Konsep ini yang mendasari pengenaan pajak penghasilan secara progresif, seperti dianut rezim perpajakan Indonesia...". Perumusan ketentuan umum perpajakan tidak boleh dimonopoli pihak pembuat aturan perpajakan saja, namun harus ada prinsip keadilan bagi subyek pajak juga. Ketentuan asas keadilan dalam konsep materialitas dan asas formil, yaitu denga uraian sebagai berikut: (1) Asas Formal: 
Sri Andriani : Voluntary Compliance Dengan Konsep Keadilan Pajak Perspektif Ibnu Khaldun Bagi Wajib Pajak

Asas tujuan yang jelas (beginsel van duetlijke doelstelling), Asas organ/lembaga yang tepat (beginsel van het juiste organ), Asas perlu pengaturan (het noodzakelijkheids beginsel), Asas dapat dilaksanakan (het beginsel van uitvoorbaarheid), Asas konsensus (het beginsel van consensus). Sedangkan (2) Asas material: Asas terminologi dan sistimatika yang benar (het beginsel van duitdelijke terminologie en duitdelijke systematiek), Asas dapat dikenali (het beginsel van de kenbaarheid), Asas perlakuan yang sama dalam hukum (het rechsgelijkheids beginsel), Asas kepastian hukum (het rechtszekerheidsbeginsel), Asas pelaksanaan hukum sesuai dengan keadaan individual (het beginsel van de individuale rechtsbedeling).

Pendapat Brotodiharjo pemungutan pajak dilakukan dengan memperhatikan hal-hal yang muncul saat pembuatan regulasi, asas dan prinsip keadiannya, dengan konsep berikut: "...hukum pajak harus dapat memberikan jaminan hukum bagi tercapainya keadilan, dan jaminan ini diberikan kepada pihak-pihak yang tersangkut di dalam pemungutan pajak, yakni pihak fiscus dan wajib pajak". Pemahan keadilan pajak adalah" "agar dapat terpenuhi asas keadilan, maka hukum pajak menempuh suatu pola pemungutan pajak yang diselenggarakan secara umum dan merata. Artinya, seluruh individu-individu memiliki hak dan kewajiban yang sama dalam hukum pajak". Sedangkan ahli bahasa (Muyasto) menytakan: "...hal tersebut terutama berarti bahwa alokasi beban pajak pada berbagai golongan masyarakat harus mencerminkan keadilan. Mengenai hal ini ada dua kriteria yang lazim digunakan untuk melihat apakah alokasi beban pajak telah mencerminkan aspek keadilan, yaitu kemampuan membayar dari wajib pajak (ability to pay), dan prinsip benefit (benefit principle)".

Hal yang penting, menurut ketentuan umum perpajakan, pemungutan pajak yang dilakukan oleh pemerintah harus memperhatikan perlindungan untuk masyarakat, kerhasiaan data, dan jaminan yang jelas jika masyarakat mulai patuh, seperti uraian berikut: “...Tetapi yang lebih penting apakah pembayar pajak dilindungi hak-haknya, jadi harus ada keseimbangan antara kewajiban dan hak sebagai pembayar pajak. Melalui undang-undang harus ada garansi objektif bahwa petugas pajak tidak boleh berlaku sewenang-wenang terhadap pembayar pajak yang telah menyetorkan sebagian penghasilannya kepada Pemerintah tanpa diberikan imbalan apapun secara langsung". Dalam konsep ibnu Khaldul tampak bahwa prinsip keadilan yang terdiri dari: (1)prinsip kenetralan, (2) prinsip kesamataraan, (3) prinsiop kemudahan, (4) produktivitas tanpa penindasan, (5) prinsip pemerataan, (6) prinsip perlakuan yang sama, (7) prinsip perlindungan

\section{Konsep Pengelolaan Pajak Prespektif Ibnu Khaldun}

Dalam Al-Quran Surah Al Baqarah : 177 juga menjelaskan bahwa Allah SWT memerintahkan kita untuk mengeluarkan harta selain Zakat. Serta di dalam surat (QS (4); 59) juga dijelaskan tentang kewajiban muslim untuk mentaati Allah SWT dan Rasulnya dan Ulil Amri diantara kamu. Hal ini menunjukkan bahwa kewajiban membayar pajak adalah salah satu kepatuhan kita kepada ulil amri yang harus kita taati. Zakat dan pajak adalah dua hal yang sama-sama wajib atas 
Sri Andriani : Voluntary Compliance Dengan Konsep Keadilan Pajak Perspektif Ibnu Khaldun Bagi Wajib Pajak

diri kaum muslim, dimana zakat digunakan hanya untuk asnaf yang delapan (fakir, miskin, amil, mu'alaf, riqab, ghorim, ibnu sabil dan fisabilillah), sedangkan pajak digunakan untuk kepentingan umum. Keduanya sama-sama bernilai ibadah. pembiayaan negara dari hasil sumber daya alam belum mencukupi, utang luar negeri akan memberati generasi mendatang sehingga membuat pajak menjadi pilihan terbaik. Pajak sesungguhnya bukanlah sumbangan, melainkan pengamanahan harta kita kepada penyelenggara pemerintahan, yang akan mereka pakai untuk kepentingan kita dan orang lain demi mewujudkan kemakmuran Bersama.

Model dinamika yang dikembangkan Ibnu Khaldun menyimpulkan bahwa suatu negara dalam mengambil kebijakan pasti akan dipengaruhi oleh faktor sosial, moral, ekonomi dan politiknya. Selain itu adanya teori-teori yang dimunculkan yaitu teori kerangka sejarah, teori ekonomi dan teori produksi. Wawancara yang dilakukan dapat menggambarkan kebijakan yang dibuat pemerintah melalui kepatuhan wajib pajak (voulentary effect) dalam salah satu program yaitu tax amnesty menunjukkan wajib pajak merasa telah ada keadilan, hal ini dapat dilihat dari data peningkatan kepatuhan wajib pajak, pendapat yang menarik adalah wajib pajak merasa tidak terbebani dan merasa lebih mudah dalam menjalankan kewajibannya. Hasil analisis wawancara diatas dapat disimpulkan bahwa kesadaran sesorang itu didahuli dari seberapa besar pengetahuan seseorang tentang hukum tersebut. sesuai dengan firman Allah Allah Surat An Nisa' ayat 63:

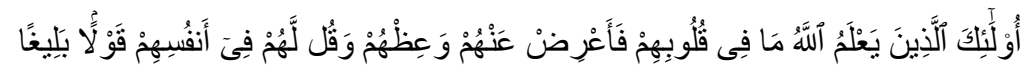

"Mereka itu adalah orang-orang yang Allah mengetahui apa yang di dalam hati mereka. Karena itu berpalinglah kamu dari mereka, dan berilah mereka pelajaran, dan katakanlah kepada mereka perkataan yang berbekas pada jiwa mereka".

Guna menambah pengetahuan sesorang perlu adanya petunjuk untuk menambah ilmu seseorang dan perlu adanya pedoman dalam mempelajarinya. dalam firman Allah telah dijelaskan bahwa Allah telah menurunkan kitab Allah sebagai petunjuk. dalam surat Al Maidah ayat 44-49. Selain itu, sebagai seorang warga negara dan muslim yang baik, sudah seharusnya mentaati peraturan pemerintah. Allah telah memerintahkan manusia untuk menaati pemimpin pemimpinnya dengan firmanNya yaitu dalam QS. An Nisa' ayat 59

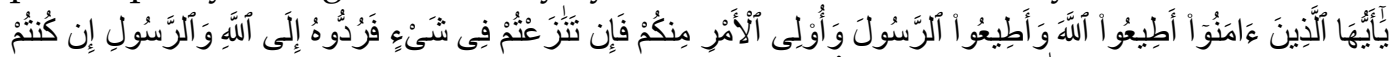

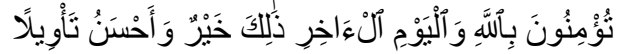

"Hai orang-orang yang beriman, ta'atilah Allah dan ta'atilah Rasul (Nya), dan ulil amri di antara kamu. Kemudian jika kamu berlainan pendapat tentang sesuatu, maka kembalikanlah ia kepada Allah (Al Qur'an) dan Rasul (sunnahnya), jika kamu benarbenar beriman kepada Allah dan hari kemudian. Yang demikian itu lebih utama (bagimu) dan lebih baik akibatnya". 
Sri Andriani : Voluntary Compliance Dengan Konsep Keadilan Pajak Perspektif Ibnu Khaldun Bagi Wajib Pajak

\section{Konsep Kepatuhan, Kesadaran, dan Keadilan}

Hasil penelitian atas konsep kepatuhan, kesadaran, dan kepatuhan ditunjukkan pada grafik-grafik berikut:

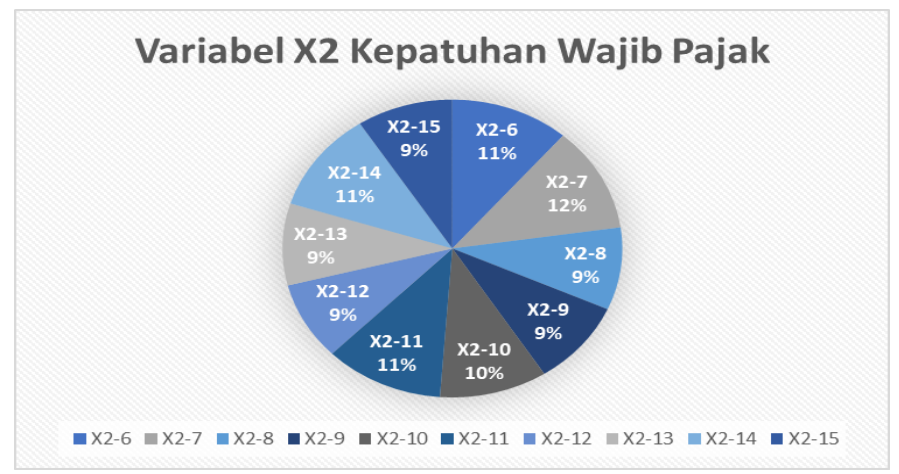

Gambar 6. Konsep Kepatuhan Wajib Pajak

Dari data yang diperoleh, dapat terlihat bahwa 11\% mendaftarkan NPWP atas kemauan sendiri, 12\% kesadaran bahwa setiap wajib pajak harus mendaftarkan diri untuk NPWP, 9\% telah mengetahui batas akhir dalam pelaporan pajak, 9\% memiliki kesadaran dan kepatuhan dalam memenuhi kewajiban perpajakan dengan menyampaikan SPT tepat waktu, 10\% wajib pajak selalu mengisi SPT sesuai dengan ketentuan perundang-undangan, 11\% teknologi informasi mempermudah pelaporan SPT sehingga mendorong wajib pajak untuk melapor sebelum batas waktu berakhir, 9\% wajib pajak mampu melakukan perhitungan pajak dengan benar, 9\% wajib pajak selalu tepat waktu dalam mebayar pajak, $11 \%$ pemahaman adanya bunga dalam tunggakan pajak akan menambah beban pajak, dan 9\% wajib pajak bersedia membayar kewajiban pajak serta tunggakan pajaknya.

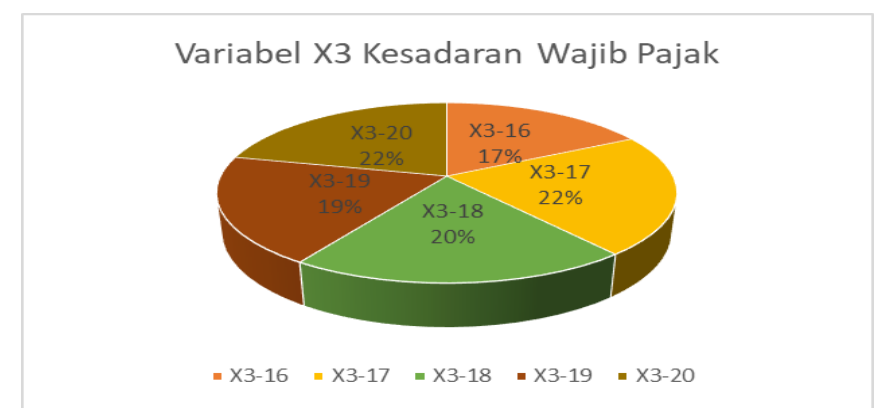

\section{Gambar 7. Konsep Kesadaran Wajib Pajak}

Dari table diata menunjukkan bahwa $17 \%$ wajib pajak menyadari bahwa pajak harus dibayar karena merupakan kewajiban saya sebagai warga Negara, 22\% menyadari pajak merupakan penerimaan terbesar kas Negara, 20\% menyadari bahwa pajak yang dibayarkan merupakan bentuk partisipasi dalam pembangunan nasional, 19\% menyadari dalam hal melaporkan pajak tepat pada waktunya, 22\% menyadari ketidakpatuhan membayar pajak dapat merugikan Negara. 
Sri Andriani : Voluntary Compliance Dengan Konsep Keadilan Pajak Perspektif Ibnu Khaldun Bagi Wajib Pajak

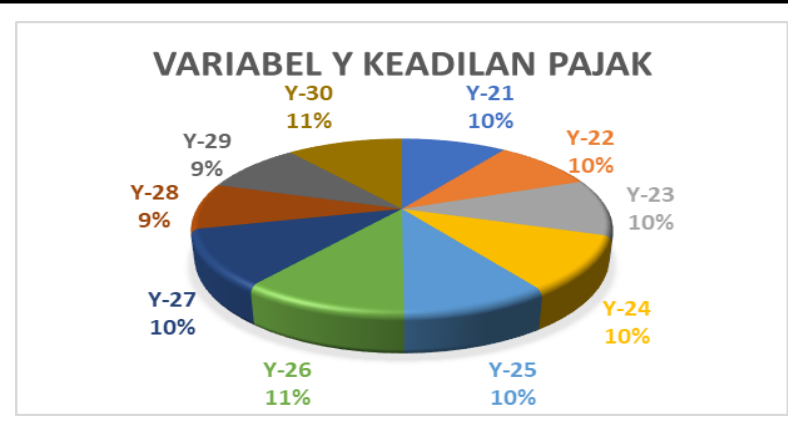

Gambar 8. Konsep Keadilan Pajak

Dari Tabel diatas bisa dilihat bahwa keadilan pajak bersifat signifikan. sehingga keadilann pajak sudah dirasakan oleh wajib pajak sesuai dengan keadilan yang mereka rasakan.

\section{KESIMPULAN}

Hasil penelitian menujukkan belum ada secara implisit yang menyebutkan bahwa keadilan dalam kepatuhan wajib pajak pada saat voulentary effect, namun saat dibahas salah satu kasusnya dengan wajib pajak dan petugas pajak, maka hampiffr semua pendapat menyebutkan bahwa konsep keadilan dalam menigkatkan kepatuhan dangat perlu dan ini sudah ada alah pelaksanaan di kantor pajak. Jika ditarik teori dari Ibnu Khaldun dapat ditarik benang merah bahwa 3 senep ibnu khandun

\section{DAFTAR PUSTAKA}

Al Quranul Karim

Al Hadist

Abdullah, Sayid Hasan. 1428/2007. Tajannubu al Dharibah fi Mizani al Figh al Islami. Majallah (Jurnal) Al Syariah wa Al Qanun, Edisi XXIX, Muharram 1428/Januari 2007.

Abdullah, Budi, 2011. Peradaban Pemikiran Ekonomi Islam, Bandung: Pustaka Setia,.

Agustiantono, Dwi. Dan Prastiwi, Andri. 2012. Analisis Faktor-faktor yang mempengaruhi Kepatuhan wajib pajak orang pribadi aplikasi TPB (Studi Empiris WPOP di Kabupaten Pati). eprints.undip.ac.id, Semarang

Ajzen, Icek. 2005. Attitudes, personality, and behavior_(2nd. Edition). Milton-Keynes, England: Open University Press,McGraw- Hill.

Arikunto, Suharsimi. 2009. Prosedur Penelitian Suatu Pendekatan dan Praktek. Edisi Revisi V. Jakarta: Rineke Cipta 
Sri Andriani : Voluntary Compliance Dengan Konsep Keadilan Pajak Perspektif Ibnu Khaldun Bagi Wajib Pajak

Bobek dan Hatfield. 2003. "An Investigation of The Theory of Planed Behavior and The Role of Moral Obligation in Tax Compliance". University of central Florida. The Universityof Texas at san Fransisco

Braithwaite, V. A., 'A. 2003. New Approach to Tax Compliance' dalam V. A. Braithwaite (ed), Taxing Democracy: Understanding Tax Avoidance and Evasion (Ashgate Pub Ltd).

Darussalam. 2010. Peningkatan Kepatuhan Wajib Pajk Melalui Pengawasan Perpajakan. International Tax, Ortax

Erich Kircler et al. 2010. A Review of Tax Complance Decisions, dalam developing alternative framework for explaining ax Complance, ed James Alm, Jorge Martinez-Vasquez dan Benno Torgler. New York:Routledge

Karim, Adiwarman, Azwar, 2008. Sejarah Pemikiran Ekonomi Islam, Jakarta:PT Radja Grafindo Persada,

Mardiasmo. (2016). Perpajakan, Edisi Revisi. Bulaksumur: Penerbit Andi.

Mutikasari, 2007. Kajian Empiris tentang Kepatuhan Wajib Pajak Badan di Perusahaan Pengolahan Industri di Surabaya. Fakultas Ekonomi. Universitas Airlangga

OECD, 2012 General Introduction on Tax Administration, presentasi disampaikan pada short course Tax Administration: Taxpayer Service di Seoul pada tanggal 23 April 2012.

Pris, K. Andarini. 2010. Dampak Dimensi Keadilan Pajak Terhadap tingkat Kepatuhan Wajib Pajak Badan. Fakultas Ekonomi, Universitas Diponegoro, Semarang

Qaradhawi, Yusuf. 2010. Fiqih Zakat, Dirasah Muqaranah li Ahkamiha wa Falsafatiha fi Dlaui al Quran wa Sunnah. Muassasah al Risalah, Beirut.

Richardson, Grant. 2006. The Impact of Tax Fairness Dimensions on Tax Compliance Behavior in an Asian Jurisdiction: The Case of Hong Kong, International Tax Journal, vol. 32, no. 1, pp. 29-42

Sri Andriani. 2010. Pengaruh Pelayanan Prima Terhadap Kepuasan Masyarakat Sejalan dengan Pemberian ISO 9000/2000 Dinas Perijianan Kota Malang. DP2MDikti: Jakarta 
Sri Andriani : Voluntary Compliance Dengan Konsep Keadilan Pajak Perspektif Ibnu Khaldun Bagi Wajib Pajak

Slamet, Agus Sucipto, Ahmad Djalaludin, Sri Andriani. 2011. Pengukuran kinerja berbasis budaya spiritual dalam rangka pelyanan prima. Lemlitbang UIN Maulana Malik Ibrahim, Malang, tidak publikas

Undang-Undang Nomor 36 Tahun 2008 tentang Pajak Penghasilan

Parwito. 2006. UU Pajak Penghasilan Penuh Distorsi. Harian Bisnis Indonesia. 